\title{
页岩气藏水平井多级压裂裂缝扩展模型研究
}

\author{
李玮 ${ }^{1 *}$, 孙文峰 ${ }^{1}$, 龚小卫 ${ }^{1}$, 郭柏云 $^{2}$, 间铁 ${ }^{1}$ \\ 1. 东北石油大学石油工程学院, 大庆 163318 ; \\ 2. Department of Petroleum Engineering, University of Louisiana at Lafayette, Lafayette 70506, USA \\ * 联系人, E-mail: our.126@126.com \\ 收稿日期: 2016-12-29; 接受日期: 2017-03-15; 网络出版日期: 2017-06-30 \\ 国家自然科学基金(编号: 51490650)资助
}

\begin{abstract}
摘要“水平井十多级压裂”技术是目前页岩气藏开发的一项核心技术, 并已取得商业化成功. 该技术的应用 有效改变了压裂的作用区域, 但对于裂缝分支的起裂和扩展程度认识的不清, 导致水力压裂设计较为粗䊅. 本 文应用最小作用量原理, 使裂缝系统的流体压力能、流体动能、弹性能、岩石表面能和摩擦损失热能构成的 拉格朗日函数满足哈密顿积分条件, 建立了预测最大储层改造体积(Stimulated Reservoir Volume, SRV) 时裂缝虚 拟个数和虚拟长度模型, 其中裂缝虚拟个数可以用来描述裂缝的复杂性. 对裂缝虚拟个数和裂缝生长率模型单 因素分析结果表明, 杨氏模量、范宁摩擦系数等对裂缝虚拟个数的影响显著, 裂缝净压力、范宁摩擦系数对裂 缝生长率的影响显著. 威远-长宁页岩的现场研究实例表明, W1 井的裂缝虚拟个数比 N1井强, W1井的储层体积 改造程度比 N1井好, 且 W1 井的裂缝复杂程度更好, 而裂缝虚拟个数概念能够反映压裂裂缝的实际复杂性. 这 为完井工程师提供了理论指导, 以提高页岩气储层井压裂改造设计和分析准确性.
\end{abstract}

关键词页岩气, 水平井, 多级压裂, 体积压裂, 裂缝复杂性

PACS: 45.20.Jj, 45.10.Hj, 02.30.Ik, 02.30.Xx

页岩气是一种潜在资源量巨大的非常规油气资 源. “水平井十多级压裂”技术是目前页岩气藏开发 的一项核心技术, 并已取得商业化成功. 水平井大幅 度提高了与页岩层中裂缝接触的可能性, 增大了与 储层的接触面积, 因此水平井开采效果良好 ${ }^{[1]}$. 多级 压裂技术则进一步扩展储层中裂缝的发育规模和交 汇程度, 因此取得了迅速的发展, 已经从大规模压裂 (Massive Fracturing, MF)发展到同步压裂(Simultaneous Fracturing, SF)、拉链压裂(Zipper Fracturing, ZF)、改
良拉链压裂(Modified-Zipper Fracturing, MZF). 大规模 压裂通过增加压裂材料的用量(压裂液和支撑剂)和压 裂级数来提高油气井的产能 ${ }^{[2]}$.

Baihly等人 ${ }^{[3]}$ 分析了大规模压裂对于美国 5 个页岩 盆地中页岩气井的性能的影响, 研究发现, 增加压裂 级数和每口井的压裂液、支撑剂的用量, 页岩气井的 初始生产率明显提高. 但随着压裂级数的增加, 压裂 裂缝之间的干扰变得显著. 对此, Wu和Pollard ${ }^{[4]}$, Olsen 等人 ${ }^{[5]}$ 认为, 天然裂缝与水力压裂裂缝进行交叉, 并诱

引用格式: 李玮, 孙文峰, 龚小卫, 等. 页岩气藏水平井多级压裂裂缝扩展模型研究. 中国科学: 物理学力学 天文学, 2017, 47: 114613

Li W, Sun W F, Gong X W, et al. Propagation model of multi-stage hydraulic fracturing for horizontal wells on shale gas reservoirs (in Chinese). Sci Sin-Phys Mech Astron, 2017, 47: 114613, doi: 10.1360/SSPMA2016-00546 
导其传播. Weng和 Siebrits ${ }^{[6]}$ 研究表明, 应力各向异性 的减小改变了水力压裂裂缝分布的几何形状, 使其从 一个双翼对称裂缝发展为复杂裂缝网络. 数值模拟表 明, 在一个超低渗透储层中建立一个交叉互通的裂缝 网络是油藏得以商业化生产的主要因素 ${ }^{[7-9]}$. 通过优化 设计每级射孔簇数、裂缝间隔、水平段压裂长度、 压裂作业顺序、支撑剂的类型和数量等参数, 可以实 现重复压裂和创建复杂的裂缝网格 ${ }^{[10]}$. 在这些参数之 间, 射孔簇的间距以及压裂段数在裂缝的产生和几何 形状中发挥主要作用. 正如Soliman等人 ${ }^{[1]}$ 指出, 由支 撑裂缝开口的应力扰动引起的裂缝之间的间距是有 限的. 然而, 如果原始应力各向异性已知, 应力扰动可 被预测, 那么压裂设计可以被优化 ${ }^{[12]}$. 压裂设计的最 新进展提供了用于创建远场压裂复杂性的技术, 以提 高油井产能 ${ }^{[13-16]}$. 受干扰导致的裂缝网络具有较高弯 曲度和复杂性的特性. 随着裂缝复杂性的增加, 也可 以观察到油气井产量的提高.

Osholake等人 ${ }^{[17]}$ 分析了影响马塞勒斯页岩气藏中 水力压裂井性能的因素. 人们普遍相信, 通过创建水 力压裂, 油井生产力正比于射孔簇的数目. 除射孔簇 外, 油井生产力也取决于当地压裂的复杂性. 对于给 定的压裂材料(液体和支撑剂), 在射孔簇的数目和分 配给每个射孔簇的量之间存在着平衡, 以增加局部裂 缝的复杂性。

根据上述研究工作, 本研究定义了一个裂缝虚拟 个数参数来表征压裂裂缝的复杂性, 并探讨其影响因 素. 该模型显示了良好的生产力与裂缝虚拟个数成正 比. 敏感性分析显示, 在一定的压裂时间内, 裂缝虚拟 个数随着流体注入速率和流体密度的增加而增加, 并 且随着最小水平应力的减小而减小.

\section{1 页岩地层多级分段体积压裂缝形态预测 的难点}

由于页岩气藏具有超低渗透率和低孔隙度的特 点, 水平井配合多级大规模水力压裂措施是页岩气藏 开发的主要技术措施. 从 20 世纪 90 年代起, 国内外学 者对油气层中水力压裂的起裂和延伸形态进行了广 泛的研究 ${ }^{[18,19]}$. 普遍的结论认为, 压裂缝的结构形态通 常为多分支的、波形和交叉形. 岩石的非均质性(天 然裂缝、孔隙、隔层等)、局部地应力和施工参数等
共同影响着主干缝和分支缝的起裂和延伸. 在页岩中, 岩石的脆性指数和微裂缝也对水力压裂缝有着重要 影响.

在采用水平井多级压裂时, 页岩地层压裂裂缝从 水平段的射孔簇通道开始起裂, 具体裂缝形态, 可以 分为裂缝簇不交叉和裂缝簇交叉. 具体如图 1 所示.

对于水平井多级压裂形成的复杂裂缝网, 无论如 何假设裂缝的扩展形态, 都会与油层实际的裂缝形态 有所偏差. 这就给后续油藏改造效果的产能预测分析 和计算带来了困难. 这也是本研究的重点和现实意义 所在.

\section{2 多级水力压裂裂缝扩展模型}

不管压裂裂缝在地下如何扩展, 其扩展的能量都 是由地面注入的流体能, 即地层中裂缝扩展需要的能 量和地面注入能量遵循能量守恒原理. 由于压裂形成 的裂缝分支具有不同的长度, 且不能精确预测, 所以 以裂缝分支平均长度为基础的裂缝复杂性表征就变 得很有意义. 将裂缝分支的平均长度定义为裂缝虚拟
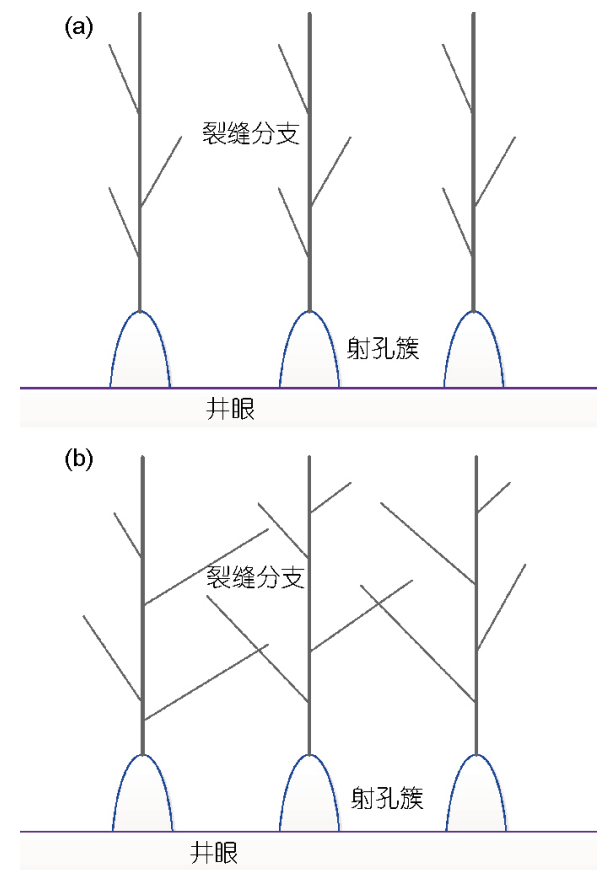

图 1 (网络版彩图)页岩气储层的多级分段压裂. (a) 裂缝 簇不交叉; (b) 裂缝簇交叉

Figure 1 (Color online) Multi-stage Hydraulic Fracturing of shale gas reservoirs. (a) Crack cluster without crossing; (b) crack cluster with crossing. 
长度, 裂缝分支的个数定义为裂缝虚拟个数. 那么裂 缝虚拟个数和裂缝虚拟长度的乘积等于裂缝分支的 总长度. 裂缝虚拟个数越多, 裂缝系统的复杂性越大, 所以虚拟个数也是评价裂缝系统复杂性的指标.

由于水力压裂和多分支缝形成的复杂性, 为简化 问题需要假设: (1) 地层岩石为各向同性的连续弹性 体; (2) 地层岩石和流体均微可压缩, 且压缩系数保持 不变; (3) 多分支压裂缝的缝高和缝宽相等, 且裂缝断 面形态为矩形裂缝; (4) 忽略压裂液受重力的影响, 缝 内各点压裂液的压力相等; (5) 在多分支缝形成过程 中的压裂液不存在滤失现象.

基于多级压裂过程中的能量平衡原理, 为了实现 对裂缝虚拟个数和裂缝虚拟长度进行定量分析, 将任 何时间内洜入射孔簇的流体能转化为裂缝内部流体 压力能、流动流体的动能、岩石的弹性能、岩石的 表面能和流动摩擦产生的热能等 5 种形式 ${ }^{[20]}$.

(1) 裂缝内部流体压力能. 裂缝内部的流体压力 能是压裂液具有的潜在能量, 是水力压裂裂缝形成的 根本能量, 具体公式如下:

$E_{p}=n h x w P$,

其中, $h$ 表示裂缝分支的平均高度, 单位 $\mathrm{m} ; n$ 表示为射 孔簇裂缝分支的数目, 无量纲; $w$ 表示裂缝分支的平均 宽度, 单位 $\mathrm{m} ; x$ 表示裂缝的平均长度, 单位 $\mathrm{m} ; P$ 表示裂 缝分支的平均压力, 单位MPa.

(2) 流动流体的动能. 裂缝内部的流体动能是流 动压裂液具有的能量, 具体公式如下:

$E_{k}=\frac{1}{2} n h x w p\left(\frac{\mathrm{d} x}{\mathrm{~d} t}\right)^{2}$,

其中, $\rho$ 表示带有支撑剂的液压流体密度, 单位 $\mathrm{kg} / \mathrm{m}^{3} ; t$ 表示原入时间, 单位s. 由于公式中裂缝分支的平均高 度 $(h)$ 、射孔簇裂缝分支的数目 $(n)$ 、裂缝分支的平均 宽度 $(w)$ 、裂缝的平均长度 $(x)$ 等参数都虚拟平均化, 所 以流动流体的动能采用了上式的形式. 在裂缝生长过 程中, 平均高度和平均缝宽是固定的, 裂缝扩展速度 的变化在平均缝长中得到反映.

(3) 岩石的弹性能. 岩石裂缝在压裂液能量作用 下发生变形时具有的能量, 具体公式如下:

$E_{s}=\frac{1}{2} n h x w\left(P-\sigma_{\mathrm{h}}\right)$,
其中, $\rho$ 表示带有支撑剂的液压流体密度, 单位 $\mathrm{kg} / \mathrm{m}^{3}$; $t$ 表示洜入时间, 单位为 $\mathrm{s} ; \sigma_{\mathrm{h}}$ 表示最小水平应力, 单位 MPa. 岩石弹性势能不能退化到稳态问题, 建模时确 实未考虑此问题.

(4) 岩石的表面能. 岩石表面能是岩石裂缝扩展 时产生的能量, 具体公式如下:

$E_{e}=n h x 2 e_{\mathrm{s}}$,

为了后续求解方便, 变化为

$E_{e}=n h x w \frac{2 e_{\mathrm{s}}}{w}$,

其中, $e_{\mathrm{s}}$ 表示岩石的表面能, 单位 $\mathrm{J} / \mathrm{m}^{2}$.

(5) 流动摩擦产生的热能:

$E_{f}=2 f n h x^{2}\left(\frac{\mathrm{d} x}{\mathrm{~d} t}\right)^{2}$,

其中, $f$ 表示范宁摩擦系数.

基于能量守恒原理, 动能、压力能、表面能、弹 性能量、摩擦耗能的和等于注入液体的能量, 可以写 出以下方程:

$P_{\mathrm{in},} q_{\mathrm{inj}} t=E_{p}+E_{k}+E_{s}+E_{e}+E_{f}$,

其中, $p_{\text {inj }}$ 表示裂缝入口的注入压力, 单位 $\mathrm{MPa} ; q_{\mathrm{inj}}$ 表示 流体注入率, 单位 $\mathrm{m}^{3} / \mathrm{s}$.

利用最小作用量原理可以计算出裂缝虚拟个数 和裂缝虚拟分支的解. 以符号 $K(t)$ 表示动能, $P(t)$ 表示 势能, $F(t)$ 表示耗散能. 定义拉格朗日函数、动作积分 函数为

$L=K(t)-P(t)$,

$I_{\sigma}=\int L \mathrm{~d} t$.

引入瑞利耗能函数, 根据哈密顿原则, 对象将按 $I_{\sigma}$ 最 小的轨迹移动, 则 $I_{\sigma}$ 达到最低时的拉格朗日函数为

$\frac{\mathrm{d}}{\mathrm{d} t}\left(\frac{\partial L}{\partial x^{\prime}}\right)-\frac{\partial L}{\partial x}=-\frac{\partial F}{\partial x^{\prime}}$.

将式(1)和(2)变形、整理、简化代入式(3)中, 整 理、化简求解高阶微分方程, 可得裂缝虚拟长度和裂 缝虚拟个数的解如下:

$x=\frac{3}{4} t^{\frac{2}{3}}\left(\frac{w}{4 f \rho}\left(3 P-\sigma_{h}+\frac{4 e_{\mathrm{s}}}{w}\right)\right)^{\frac{1}{3}}$. 
$n=\frac{p_{\mathrm{inj}} q_{\mathrm{inj}} t}{h x\left[w\left(P+\frac{1}{2}\left(P-\sigma_{h}\right)+\frac{2 e_{\mathrm{s}}}{w}\right)+\rho\left(\frac{1}{2} w+2 f x\right)\left(\frac{\mathrm{d} x}{\mathrm{~d} t}\right)^{2}\right]}$.

裂缝生长率公式如下:

$\frac{\mathrm{d} x}{\mathrm{~d} t}=\frac{1}{2} t^{-\frac{1}{3}}\left(\frac{w}{4 f \rho}\left(3 P-\sigma_{h}+\frac{4 e_{\mathrm{s}}}{w}\right)\right)^{\frac{1}{3}}$.

上述公式中的缝宽可以使用式(7):

$w=\frac{\pi h\left(P-\sigma_{h}\right)}{4} \frac{1-\mu^{2}}{E}$.

在流体注入的任何给定时间内, 根据上述式子即 可分析裂缝虚拟长度和裂缝虚拟个数. 本研究中裂缝 虚拟个数 $n$ 表示裂缝系统复杂性的指标.

\section{3 多级压裂储层体积改造程度的预测}

储层体积改造可以被定义为已经受到增产影响 的储层体积 ${ }^{[21]}$. 在上述公式计算得到的裂缝虚拟长度 和裂缝虚拟个数的基础上, 可以描述增产措施的储层 体积改造情况.

本研究建立的模型给出裂缝虚拟长度和裂缝虚 拟个数, 但没有考虑裂缝分支在油藏中的生长方向. 在存在水平应力各向异性的油藏中, 裂缝生长方向受 水平应力差异的影响, 假设储层体积改造的范围是椭 圆形, 其中长轴线与最大水平应力方向相同, 而短轴 线与最小水平应力方向相同. 由于裂缝模型的复杂性 可以由式(3)-(5)来分析说明, 也基于储层改造地区是 一个带有射孔簇的椭圆形中心的假设, 对于每个射孔 簇来说, 储层体积改造可描述为储层改造地区和裂缝 平均长度的产物. 定义 $L_{x}$ 和 $L_{y}$ 分别为半短轴和半长轴, 其中 $L_{x} / L_{y}$ 是通过原位水平应力各向异性确定的. 如果 假设裂缝分支的平均长度等于 $\left(L_{x}+L_{y}\right)$ 的 $1 / 2, L_{x} / L_{y}$ 等于 最小水平应力和最大水平应力的比值 $\left(\sigma_{\mathrm{h}} / \sigma_{\mathrm{H}}\right)$, 那么储 层体积改造就可以写成如下形式:

$(S A R)_{i}=\pi L_{x} L_{y}=4 \pi x_{i}^{2} \frac{\frac{\sigma_{\mathrm{H}}}{\sigma_{\mathrm{h}}}}{\left(1+\frac{\sigma_{\mathrm{H}}}{\sigma_{\mathrm{h}}}\right)^{2}}$,

$$
S R V=\sum_{1}^{n_{c}} 4 \pi x_{i}^{2} h_{i} \frac{\frac{\sigma_{\mathrm{H}}}{\sigma_{\mathrm{h}}}}{\left(1+\frac{\sigma_{\mathrm{H}}}{\sigma_{\mathrm{h}}}\right)^{2}},
$$

其中, $x_{i}$ 表示第 $i$ 射孔簇中, 裂缝的平均长度, 单位 $\mathrm{m}$; $h_{i}$ 表示第 $i$ 个射孔簇中裂缝的平均高度, 单位 $\mathrm{m} ; n_{c}$ 表示 射孔簇的数目; $\sigma_{\mathrm{H}}$ 表示最大水平地应力, 单位 $\mathrm{MPa} ; \sigma_{\mathrm{h}}$ 表示最小水平地应力, 单位MPa.

在推导式(9)时,假设储层改造区域的相邻射孔簇 之间没有重叠区域. 现实中, 在考虑射孔簇间距时, 应 避免储层改造区域的重叠, 其间距大小由最佳注入时 间的裂缝分支平均长度所决定.

\section{4 模型的影响因素分析}

为了多级压裂优化设计和油井产能的最大化, 探讨影响裂缝复杂性指标的因素是有必要的. 通 过式(4)-(6)得出, 裂缝延伸的变化趋势与裂缝虚拟 个数是注入时间的函数.

为了了解裂缝净压力、页岩表面能、杨氏模量、 范宁摩擦系数等对裂缝的生长率和虚拟个数的影响, 绘制了图2-9.

这些图中给出了裂缝生长率和裂缝虚拟个数的分 布曲线. 由图可知, 在流体注入前期, 裂缝分支的生长 速度很快, 随着注入时间的增加, 裂缝分支生长变缓. 裂缝虚拟个数随注入时间成幂律函数增加. 这就为射 孔簇增长率与压裂液注入体积不成正比的事实提供了

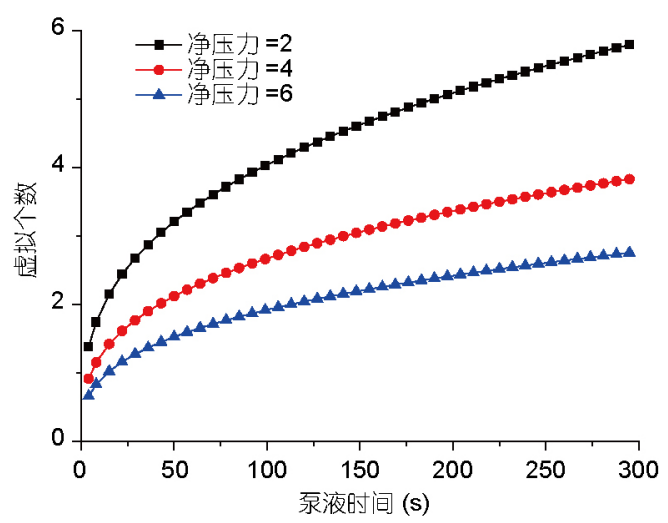

图 2 (网络版彩图)净压力对裂缝虚拟个数的影响 Figure 2 (Color online) Effect of net pressure on the pseudo population of fractures. 


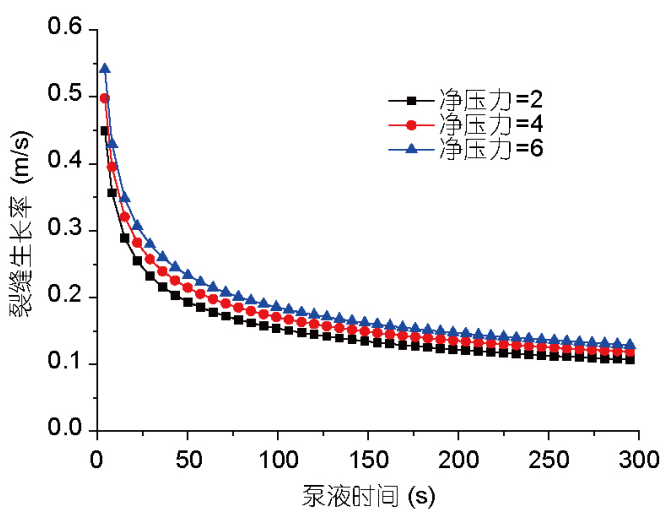

图 3 (网络版彩图)净压力对裂缝生长率的影响 Figure 3 (Color online) Effect of net pressure on the growth rate of fractures.

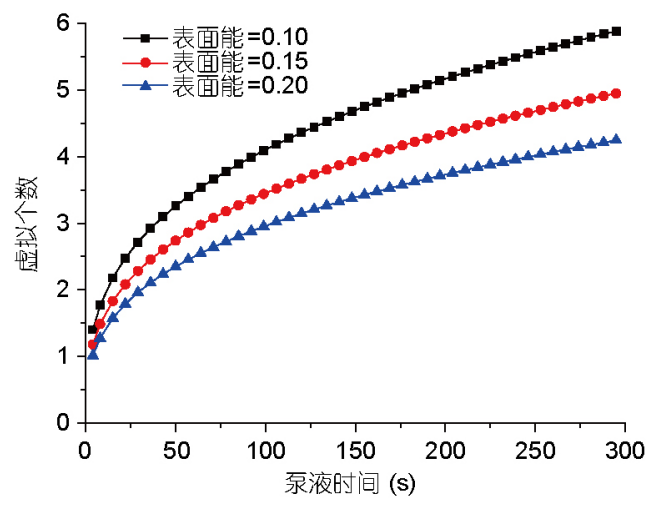

图 4 (网络版彩图)表面能对裂缝虚拟个数的影响

Figure 4 (Color online) Effect of surface energy on the pseudo population of fractures.

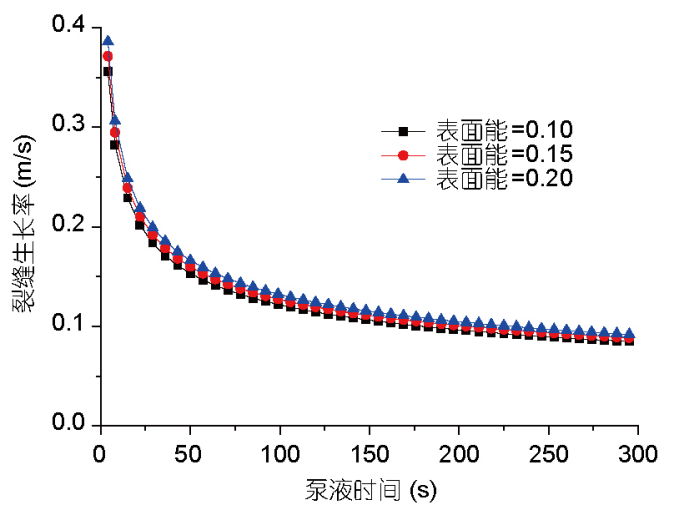

图 5 (网络版彩图)表面能对裂缝生长率的影响

Figure 5 (Color online) Effect of surface energy on the growth rate of fractures.

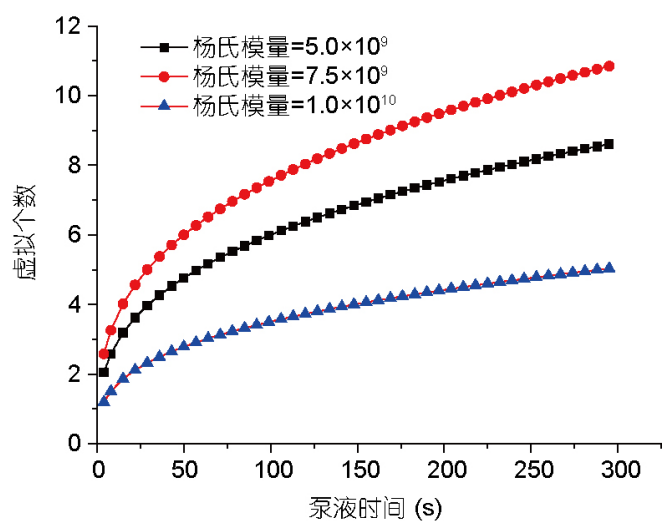

图 6 (网络版彩图)杨氏模量对裂缝虚拟个数的影响 Figure 6 (Color online) Effect of Young's modulus on the pseudo population of fractures.

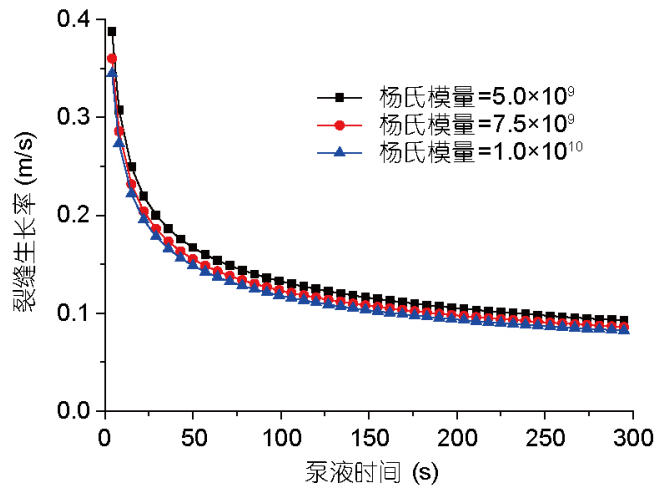

图 7 (网络版彩图)杨氏模量对裂缝生长率的影响

Figure 7 (Color online) Effect of Young's modulus on the growth rate of fractures.

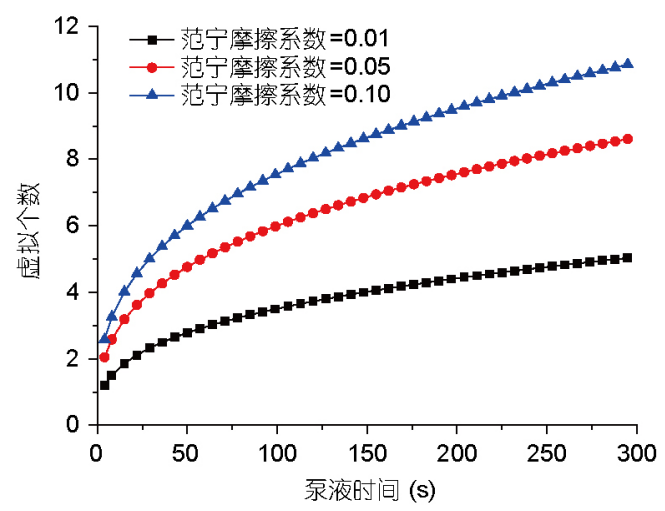

图 8 (网络版彩图) 范宁摩擦系数对裂缝虚拟个数的影响 Figure 8 (Color online) Effect of Fanning friction factor on the pseudo population of fractures. 


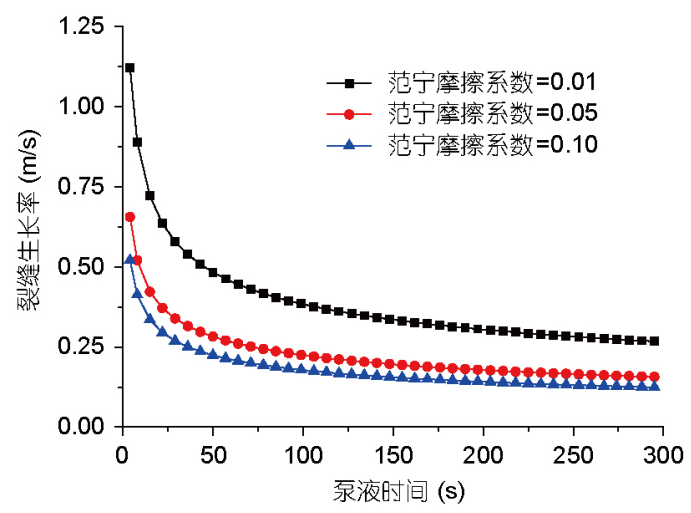

图 9 (网络版彩图)范宁摩擦系数对裂缝生长率的影响 Figure 9 (Color online) Effect of Fanning friction factor on the growth rate of fractures.

一个理论解释.

从图2-9可知, 随时间的增长, 裂缝的生长率呈负 幂律分布, 虚拟个数随时间呈幂律分布. 杨氏模量、 范宁摩擦系数等对裂缝虚拟个数的影响显著. 裂缝净 压力、页岩表面能对裂缝虚拟个数的影响不显著. 裂 缝净压力、范宁摩擦系数对裂缝生长率的影响显著. 杨氏模量、页岩表面能对裂缝生长率的影响不显著. 其主要原因是地面原注的流体是水力压裂裂缝形成 的根本, 压裂的裂缝生长率变化则主要受注入流体速 率的影响. 而页岩的杨氏模量是岩石的自身参数, 不 能自主形成压裂裂缝, 但会影响压裂裂缝的形态, 即 它们对裂缝虚拟个数影响显著, 对裂缝生长率影响不 显著.

根据储层体积改造的计算模型绘制图10. 图10表 明, 在压裂开始时, 储层体积改造迅速增加, 随着注入 时间的增加, 逐渐变慢. 最大水平主应力和最小水平 主应力的比值对储层体积改造有影响, 其分布规律为 主应力比值越大, 储层体积改造越大.

\section{5 现场应用实例分析}

研究表明, 用裂缝分支的虚拟个数来分析裂缝复 杂性, 可以真实反映多级水力压裂的复杂性. 以 $\mathrm{M}$ 区块 作为研究实例, M区块位于四川南部的威远-长宁地区, 目的层为下志留统龙马溪组-上奥陶统五峰组, 倾角小 于 $5^{\circ}$, 成宽缓向斜轴部显著特征, 区块目的层埋深为 1600-3600 m, 其中威远地区的面积约为 $250 \mathrm{~km}^{2}$, 初步 计算页岩气地质储量为 $1890 \times 10^{9} \mathrm{~m}^{3}$, 长宁地区的地质 储量为 $920 \times 10^{9} \mathrm{~m}^{3}$. 该区龙马溪组为浅水 - 深水陆棚相

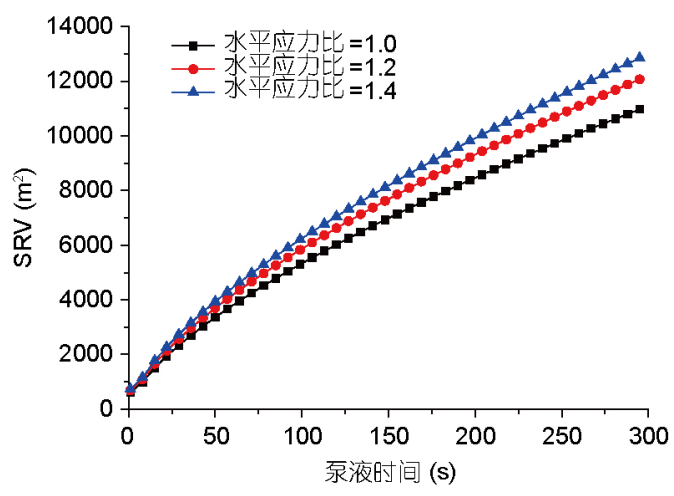

图 10 (网络版彩图)储层体积改造的计算模型

Figure 10 (Color online) Model-computed of the stimulated reservoir volume.

沉积, 因加里东运动抬升剥蚀地层残余厚度100-300m, 页岩地层厚度为 $200-400 \mathrm{~m}$, 富含有机质的页岩厚度为 20-260 m, 总有机碳(Total Organic Carbon, TOC)含量平 均大于 $1.8 \%$. 现场测试结果表明, 研究区内龙马溪组页 岩含气量在 $0.3-5.09 \mathrm{~m}^{3} / \mathrm{t}$, 平均为 $1.85 \mathrm{~m}^{3} / \mathrm{t}$. 其中威远地 区W1井的页岩岩心样品含气量为 $0.3-5.09 \mathrm{~m}^{3} / \mathrm{t}$, 平均为 $1.82 \mathrm{~m}^{3} / \mathrm{t}$; 长宁地区 $\mathrm{N} 1$ 井的岩心含气量为 $0.9-3.50 \mathrm{~m}^{3} / \mathrm{t}$, 平均为 $1.93 \mathrm{~m}^{3} / \mathrm{t}$, 储层为低孔、超低渗透页岩储层, 孔 隙度 $<4.0 \%-6.5 \%$, 渗透率 $<10^{-19} \mathrm{~m}^{2}$, 裂缝虽以钻井诱导 缝为主, 但仍发现页岩基质、有机质中存在大量微小 孔洞和裂缝. 综上所述, 页岩气储层整体表现为低孔 隙度、含气量较高等特点.

提取 M区块两口压裂井数据, 如表 1 和 2 所示. 应 用式(4)-(7)分析两口井压裂情况, 具体如图11和12所 示. 两口井中的裂缝虚拟个数的分析显示, W1井压裂

表 1 W1井数据计算参数表

Table 1 A summary of competed parameters data of Well W1

\begin{tabular}{ccc}
\hline 名称 & 符号 & 取值 \\
\hline 排量 & $Q$ & $8 \mathrm{~m}^{3} / \mathrm{min}$ \\
缝内平均压力 & $P$ & $36 \mathrm{MPa}$ \\
最小水平应力 & $\sigma_{\mathrm{h}}$ & $30.19 \mathrm{MPa}$ \\
最大水平应力 & $\sigma_{\mathrm{H}}$ & $48.17 \mathrm{MPa}$ \\
平均缝高 & $h$ & $20 \mathrm{~m}$ \\
表面能 & $e_{\mathrm{s}}$ & $0.15 \times 10^{6} \mathrm{~J} / \mathrm{m}^{2}$ \\
范宁摩擦系数 & $f$ & 0.1 \\
杨氏模量 & $E$ & $4.9 \times 10^{4} \mathrm{MPa}$ \\
泊松比 & $v$ & 0.18 \\
\hline & &
\end{tabular}


表 2 N1井数据计算参数表

Table 2 A summary of competed parameters data of Well N1

\begin{tabular}{ccc}
\hline 名称 & 符号 & 取值 \\
\hline 排量 & $Q$ & $7 \mathrm{~m}^{3} / \mathrm{min}$ \\
缝内平均压力 & $P$ & $62 \mathrm{MPa}$ \\
最小水平应力 & $\sigma_{\mathrm{h}}$ & $55.14 \mathrm{MPa}$ \\
最大水平应力 & $\sigma_{\mathrm{H}}$ & $76.30 \mathrm{MPa}$ \\
平均缝高 & $h$ & $20 \mathrm{~m}$ \\
表面能 & $e_{\mathrm{s}}$ & $0.19 \times 10^{6} \mathrm{~J} / \mathrm{m}^{2}$ \\
范宁摩擦系数 & $f$ & 0.1 \\
杨氏模量 & $E$ & $5.9 \times 10^{4} \mathrm{MPa}$ \\
泊松比 & $v$ & 0.21 \\
\hline
\end{tabular}

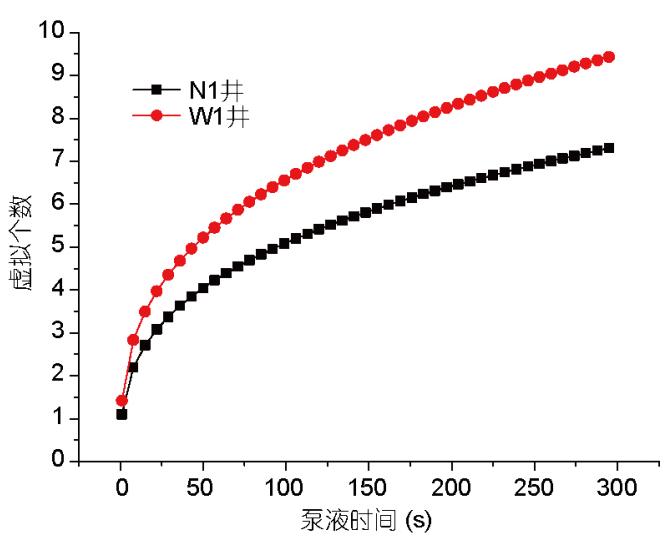

图 11 (网络版彩图) W1井和N1井的裂缝虚拟个数

Figure 11 (Color online) The pseudo population of fractures in well W1 and well N1.

得到的裂缝虚拟个数是 $9.4, \mathrm{~N} 1$ 井压裂得到的裂缝虚 拟个数是 7.3. 这说明 $\mathrm{W} 1$ 井的裂缝复杂性指标比 $\mathrm{N} 1$ 井 强, 后续的开采也证明了这一点.

裂缝的虚拟个数是描述水力压裂裂缝复杂程度 和油藏改造体积的一种重要指标, 探讨裂缝虚拟个数 对多级压裂设计的影响和最大限度地提高油井产能 优化的因素是非常有必要的. 多级水力压裂最可控的

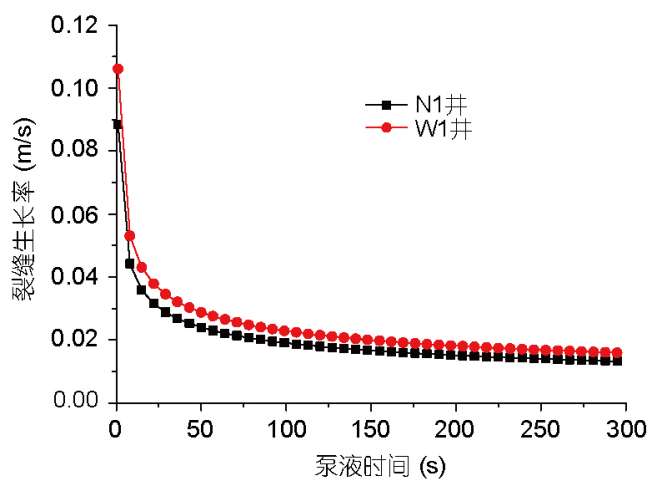

图 12 (网络版彩图) W1井和 N1井的裂缝生长率的影响 Figure 12 (Color online) The growth rate of fractures in well W1 and well N1.

变量是阶段流体喷射时间 $(t)$ 和喷射速率 $\left(q_{\mathrm{inj}}\right)$, 该参数 也是模型中主要的控制类参数.

\section{6 结论}

(1) 建立了水平井多级压裂裂缝虚拟个数和裂缝 生长率模型, 其中裂缝生长率模型呈负幂律分布, 裂 缝虚拟个数随时间呈幂律分布, 通过该模型可以分析 压裂改造体积的大小和程度. (2) 对模型的裂缝净压 力、杨氏模量、范宁摩擦系数、页岩表面能进行了 单因素分析, 杨氏模量、范宁摩擦系等对裂缝虚拟个 数的影响显著. 裂缝净压力、范宁摩擦系数对裂缝生 长率的影响显著. (3) 威远-长宁页岩的案例研究表明, $\mathrm{W} 1$ 井的裂缝虚拟个数比 $\mathrm{N} 1$ 井强, $\mathrm{W} 1$ 井的储层体积改 造程度比 $\mathrm{N} 1$ 井好, 且. W1井的裂缝复杂程度更好. 因 此, 裂缝虚拟个数是用于表征页岩气藏中水力压裂复 杂性的有意义的参数. (4) 储层体积改造与泵入时间 成非线性增加. 在每一阶段压裂的短时间内, 通过快 速百入致密和黏性液压流体, 可使储层体积改造效率 达到最大化. 基于所给裂缝分支的平均长度, 射孔簇 间距应通过最佳泵入时间进行优化.

\section{参考文献}

$1 \mathrm{Lu} \mathrm{W}, \mathrm{Li}$ Q, Wan F L. On the domestic and foreign development of shale gas well hydraulic fracturing technology (in Chinese). Energy Energy Conserv, 2012, 12: 115-122 [卢伟, 李强, 万方来. 国内外页岩气井水力压裂技术的发展及探讨. 能源与节能, 2012, 12: 115-122]

2 Lee Matthews H, Schein G. Stimulation of gas shale: They're all the same-right? In: Proceedings of SPE Hydraulic Fracturing Technology Conference. College Station, 2007

3 Baihly J, Altman R, Malpani R, et al. Shale gas production decline trend comparison over time and basins. In: Proceeding of SPE Annual Technical Conference and Exhibition. Florence, 2010 
4 Wu H, Pollard D D. Imaging 3-D fracture networks around boreholes. Inner Mongolia Petrochem Ind, 2009, 86: 593-604

5 Olsen T, Bratton T, Thiercelin M. Quantifying proppant transport for complex fractures in unconventional formations. In: Proceedings of SPE Hydraulic Fracturing Technology Conference. The Woodlands, 2009

6 Weng X, Siebrits E. Effect of production induced stress field on refracture propagation and pressure response. In: Proceedings of SPE Hydraulic Fracturing Technology Conference. College Station, 2007

7 Nagel N, Gil I, Sanchez-Nagel M. Simulating hydraulic fracturing in real fractured rocks-overcoming the limits of pseudo 3D models. In: Proceedings of SPE Hydraulic Fracturing Technology Conference. The Woodlands, 2011

8 Warpinski N R, Mayerhofer M J, Vincent M C, et al. Stimulating unconventional reservoirs: Maximizing network growth while optimizing fracture conductivity. J Canadian Petrol Technol, 2009, 48: 39-51

9 Cipolla C L, Lolon E, Erdle J C, et al. Reservoir modeling in shale-gas reservoirs. In: Proceedings of SPE Eastern Regional Meeting. Charleston, 2009

10 Mayerhofer M J, Lolon E, Warpinski N R, et al. What is stimulated reservoir volume? In: Proceedings of SPE Production and Operations. New York, 2010

11 Soliman M Y, East L E, Adams D. Geomechanics aspects of multiple fracturing of horizontal and vertical wells. In: Proceedings of SPE Drilling and Completion. Bakersfield, 2008

12 Soliman M Y, East L E, Augustine J R. Fracturing design aimed at enhancing fracture complexity. In: Proceedings of SPE Europec/EAGE Annual Conference and Exhibition. Barcelona, 2010

13 East L E, Soliman M Y, Augustine J R. Methods for enhancing far-field complexity in fracturing operations. In: Proceedings of SPE Production and Operations. New York, 2010

14 Cipolla C L, Warpinski N R, Mayerhofer M, et al. The relationship between fracture complexity, reservoir properties and fracture-treatment design. In: Proceedings of SPE Production and Operations. New York, 2010

15 Roussel N P, Sharma M M. Optimizing fracture spacing and sequencing in horizontal-well fracturing. In: Proceedings of SPE Production and Operations. Lafayette, 2011

16 Waters G, Dean B, Downie R, et al. Simultaneous hydraulic fracturing of adjacent horizontal wells in the Woodford shale. In: Proceedings of SPE Hydraulic Fracturing Technology Conference. The Woodlands, 2009

17 Osholake T, Wang J Y, Ertekin T. Factors affecting hydraulically fractured well performance in the marcellus shale gas reservoirs. J Energy Resour Technol, 2013, 135: 529

18 Branagan P T, Peterson R E, Warpinski N R, et al. Propagation of a hydraulic fracture into a remote observation wellbore results of c-sand experimentation at the GRI/DOEM-site project. In: Proceedings of SPE Annual Technical Conference and Exhibition. San Antonio, 1997

19 Warpinski N R, Branagan P T, Peterson R E, et al. An interpretation of M-site hydraulic fracture diagnostic results. In: Proceedings of SPE Rocky Mountain Regional/Low-Permeability Reservoirs Symposium. Denver, 1998

20 Guo B Y, Jiang S X. Use of calculus of variations and energy method to characterize volume fracturing on shale gas/oil reservoirs. In: Proceedings of International Mechanical Engineering Congress \& Exposition. Houston, 2015

21 Mayerhofer M J, Lolon E P, Warpinski N R, et al. What is stimulated reservoir volume? In: Proceeding of SPE Production and Operations. New York, 2010 


\title{
Propagation model of multi-stage hydraulic fracturing for horizontal wells on shale gas reservoirs
}

\author{
LI Wei ${ }^{1 *}$, SUN WenFeng ${ }^{1}$, GONG XiaoWei ${ }^{1}$, GUO BaiYun ${ }^{2} \&$ YAN Tie ${ }^{1}$ \\ ${ }^{1}$ School of Petroleum Engineering, Northeast Petroleum University, Daqing 163318, China; \\ ${ }^{2}$ Department of Petroleum Engineering, University of Louisiana at Lafayette, Lafayette 70506, USA
}

Multi-stage hydraulic fracturing of horizontal wells is a key technique used for exploiting shale gas reservoirs at present. Moreover, it has become a commercially successful technique. The application of this technique has changed the fracturing area effectively. Due to the lack of the knowledge about the initiation and extension of the fracture branches, the hydraulic fracturing design is rough. The application of the minimum action principle makes the Lagrangian function satisfy the Hamiltonian integral condition, and the Lagrangian function is composed of the fluid pressure energy, fluid kinetic energy, elastic energy, rock surface energy and frictional loss energy. The virtual number and virtual length models of fracture are established, which can describe the complexity of fractures. The single factor analysis on the virtual number model and the growth rate model of fracures show that the Young's modulus and Fanning's friction coefficient have a significant effect on the number of fractures, and the net pressure and Fenning friction coefficient have a significant effect on the growth rate of fractures. The field study in Weiyuan-Changning block show that the virtual number of fractures in W1 well is higher than that of $\mathrm{N} 1$ well, and the reservoir volume of $\mathrm{W} 1$ well is better than that of $\mathrm{N} 1$ well, and the complexity of W1 well is better. The virtual number of fractures can reflect the actual complexity, which provides theoretical guidance for completion engineers to improve the design and analysis accuracy of shale gas reservoir fracturing.

shale gas, horizontal wells, multistage fracturing, volume fracturing, fracture complexity

PACS: 45.20.Jj, 45.10.Hj, 02.30.Ik, 02.30.Xx

doi: $10.1360 /$ SSPMA2016-00546 